\title{
The Effect of Strategic Vision for the University Authorities in Administrating the Internal Client: A Case Study at Zarqa University
}

\author{
Khaled Abdulwahab Alzeaideen ${ }^{1} \&$ Majed Abdel-Mohdi Masadeh ${ }^{1}$ \\ ${ }^{1}$ Associate Professor at Department of Business Administration, Faculty of Economics and Administrative \\ Sciences, Zarqa University, Jordan \\ Correspondence: Khaled Abdulwahab Alzeaideen, Associate Professor at Department of Business Administration, \\ Faculty of Economics and Administrative Sciences, Zarqa University, Jordan. E-mail: m.alzboon@ju.edu.jo
}

Received: April 19, 2018

doi:10.5539/mas.v12n6p97
Accepted: May 2, 2018

Online Published: May 29, 2018

URL: https://doi.org/10.5539/mas.v12n6p97

\begin{abstract}
The study aims at identifing the concept of strategic vision of the authorities in Zarqa University, identifing the most important elements, and proposing the appropriate mechanisms to meet the future challenges facing the university leader as a result of competition and how to maintain the teaching and non-teaching staff within the institution to enhance loyalty of the 'internal client ' in the future. Strategic vision variables were used; future status was determined, goals achieved by the vision were achieved, university culture was selected, and the appropriate strategy was chosen as independent variables affecting a dependent variable that is is the internal client relations management. The researchers collected the initial data of the study by means of a special questionnaire. The sample consists of (115) out of 300 faculty members at Zarqa University of various qualifications, ranks and experience.

The results of the analysis show that there is a strong and significant effect on all elements of the strategic vision on internal client relationship management, and demographic variables (gender, age group, job title and years of experience) contributed intrinsically to the response of the sample regarding the adoption of the strategic vision factors in managing the internal client relations.

Based on the findings of the study, the researchers proposed a number of recommendations to the administration of the university, focusing on spreading and supporting positive culture among faculty members, setting specific and clear objectives for the future to all university employees, along with constructing lucid future strategic directions, and updating the vision and mission of the institution. It is also recommended to comprehensively expand the study of the impact of strategic and other organizational factors; and programs and plans of management development on improving the management of relationships with the internal client of the University.
\end{abstract}

Keywords: concept of strategic vision, Zarqa University

\section{Introduction}

Dealing with time and the movement of the development and change under the rule of instability and uncertainty in the present time necessitate the identification of the organization's paths and directions in order to penetrate the unknown and develop the intellectual capacities necessary to foresee the future possibilities and to bring the means required for confrontation. Therefore, recognizing the great challenges surrounding the internal and external premises of the organization depends to a great extent on the ability to make the most of all knowledge and experience. The strategic leader is one of the key elements of the organization based on its ability to visualize the future of the organization and determine the direction of its business (Al-Naemi, 2003).

Universities constitute the most important part of the educational process, which leads to the importance and enhancement of its ability to achieve its objectives and attention to the adequacy of faculty members and provide the necessary material and administrative resources, which are available in the presence of a group of administrators and authorities who are capable of formulating policies and objectives as a scientific institution that seeks to spread knowledge and contribute effectively to the process of intellectual and moral construction of the nation. Therefore, the university leadership is the focus of the administrative process, and its importance plays an active role in all aspects of the administrative process to make it more effective towards achieving the goals. The university leadership in the academic community represented by its principals is the focus of administrative and scientific efficiency at the university. The better the qualifications of these leaders, the stronger their role in 
achieving the university goals required, and the most efficient means available (Dahawi and Al-Malihi, 2011).

In addition, the strategists constitute an integral part of strategy making and the institution success. The organization is managed by individuals who have the greatest stake in the formulation and implementation of the strategy and its evaluation, which requires a logical and inevitable interaction between the leadership and the internal client and the future. The strategic vision is one of the types, capabilities and tasks of successful and forward-looking leadership because of the essence of the leadership and university process, which is linked to the range of capabilities possessed by the strategic leader at the university, (Sakram, 2003)

This means that organizations seek to have a better relationship with their customers. The stronger the relation with the client $s$, the greatest level of excellence will be achieved in the organization with its competitors. It is based on the collection and integration of client data, data analysis and evaluation according to their permanent and expected value (Kotler, 2014).

\section{The Problem and the Questions of the Study}

It is the responsibility of the university authorities to build a clear strategic vision to promote differentiation for the future environmental need and to develop appropriate strategies to confront competition at the level of providing educational service to the leading role that the university has in the development of society as a source of intellectual and cultural radiation. Therefore, a future vision should be formulated for what the university will have for the coming years with the degree of its interest in the internal customer.

Hence, the study problem can be summed up by the following two main questions:

1. What is the level of evaluation of the members of the faculty of strategic vision in the management of internal client relations at Zarqa University?

2. Is there a significant impact of strategic vision in internal client relations management at Zarqa University?

\section{The Importance of Studying}

The importance of this study lies in the following points:

1) To highlight the effective administrative ability to lead critical situations that may face them in the future.

2) The importance of creativity and innovation in achieving the desired future vision of the university and the ability of the leader to transfer that vision to the members of the university.

3) Instilling confidence among working individuals and their visibility as part of the administrative process.

4) Diagnosing future challenges that negatively affect the work of the university and the use of appropriate strategies to resolve the crises that may face.

5) Keeping pace with technological developments in the field of university work, especially after the growth and development of open universities and universities specialized in distance education and e-learning.

\section{Objectives of the Study}

This study aims to achieve the following objectives:

1) Identify the concept of strategic vision and its importance to the university leader, and identify the most important elements of the strategic vision.

2) Proposing the appropriate mechanisms to meet the future challenges facing the university leader as a result of competition and how to maintain the teaching staff and other members.

3) Increase the loyalty of employees (internal customer) within the university organization to their educational organization in the future.

4) Measuring the impact of the strategic vision of the university leadership in the management of internal client relations at Zarqa University.

5) Provide a set of suggestions and recommendations that should be taken into account in applying the variables of strategic vision at Zarqa University based on the university leadership and internal client relations.

\section{The Proposed Study Model}

In light of the problem of the study, its questions and objectives, and the importance involved, the study model was proposed to describe the relationship between the variables of the study (The Effect of Strategic Vision for the University Authorities in Administrating the Internal Client: A Case Study at Zarqa University) 
As shown in Figure (1) below:

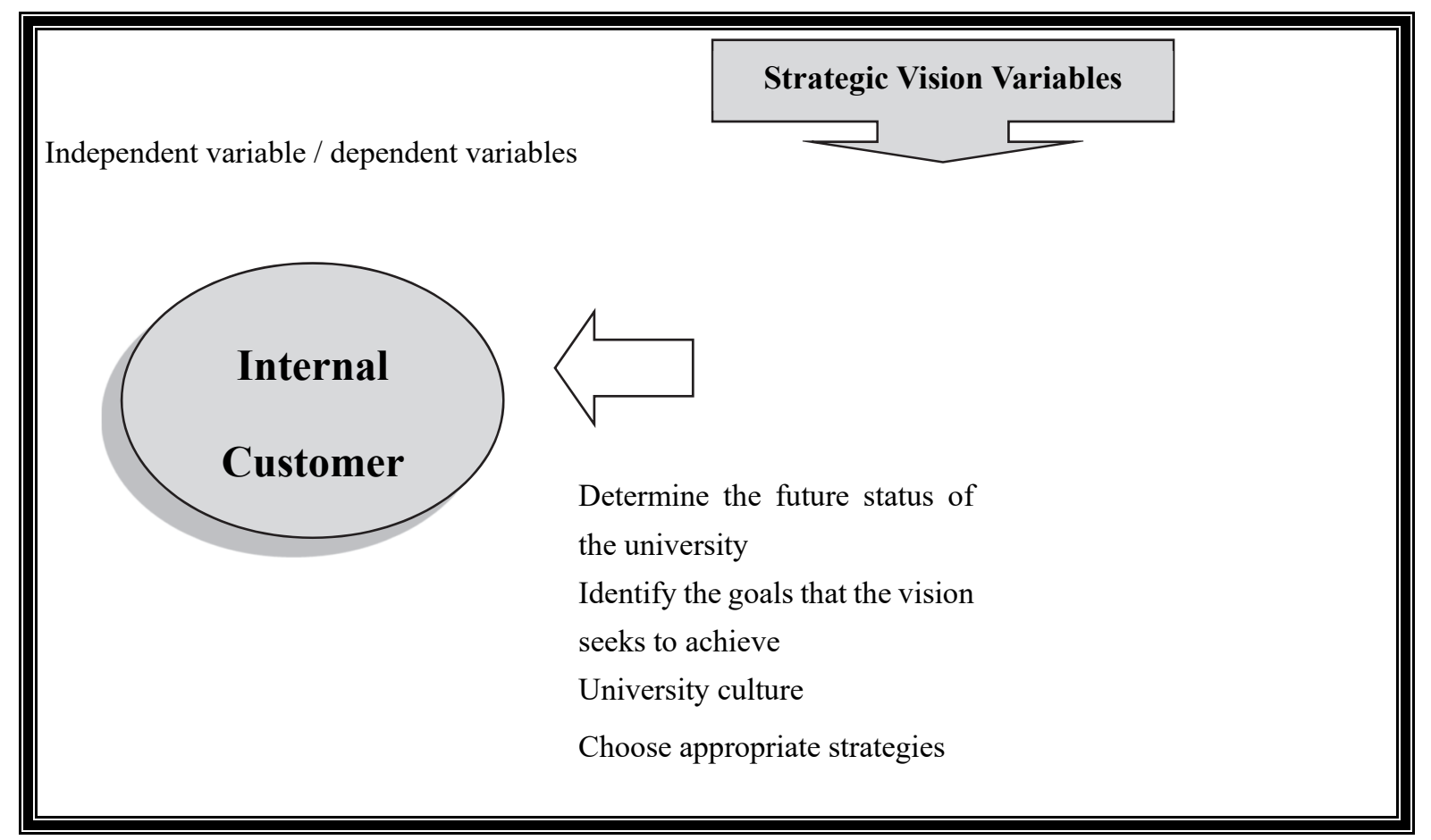

Figure (1). The Proposed Study Model

Source: Prepared by the researcher

\section{The Hypotheses of the Study}

\subsection{The First Hypothesis}

There is no statistically significant effect at the level of significance $(\alpha \leq 0.05)$ for the strategic vision elements of (determining future status, goal setting, university culture, choice of appropriate strategies) in internal client relations management at Zarqa University.

The following sub-hypotheses emerge:

1) There was no statistically significant effect at the level of significance $(\alpha \leq 0.05)$ for the element of determining the future status in internal client relations management at Zarqa University.

2) There was no statistically significant effect at the level of significance $(\alpha \leq 0.05)$ for the element of determining the goal setting in internal client relations management at Zarqa University.

3) There was no statistically significant effect at the level of significance $(\alpha \leq 0.05)$ for the element of determining the university culture in internal client relations management at Zarqa University.

4) There was no statistically significant effect at the level of significance $(\alpha \leq 0.05)$ for the element of determining the choice of appropriate strategies in internal client relations management at Zarqa University.

\subsection{The Second Hypothesis}

There are no statistically significant differences at the level of significance $(\alpha \leq 0.05)$ between the responses of the study sample members on the adoption of the elements of the strategic vision in the management of internal client relations due to the personal and functional characteristics of (gender, age groups, job title, years of experience, academic qualification, and academic level)

The following sub-hypotheses emerge:

1) There are no statistically significant differences $(\alpha \leq 0.05)$ between the responses of the study sample members on the adoption of the elements of the strategic vision in the management of internal client relations at Zarqa University attributed to the variable (gender).

2) There are no statistically significant differences $(\alpha \leq 0.05)$ between the responses of the study sample members on the adoption of the elements of the strategic vision in the management of internal client relations at Zarqa 
University attributed to the variable (age groups).

3) There are no statistically significant differences $(\alpha \leq 0.05)$ between the responses of the study sample members on the adoption of the elements of the strategic vision in the management of internal client relations at Zarqa University attributed to the variable (job title).

4) There are no statistically significant differences $(\alpha \leq 0.05)$ between the responses of the study sample members on the adoption of the elements of the strategic vision in the management of internal client relations at Zarqa University attributed to the variable (years of experience).

5) There are no statistically significant differences $(\alpha \leq 0.05)$ between the responses of the study sample members on the adoption of the elements of the strategic vision in the management of internal client relations at Zarqa University attributed to the variable (academic qualification).

6) There are no statistically significant differences $(\alpha \leq 0.05)$ between the responses of the study sample members on the adoption of the elements of the strategic vision in the management of internal client relations at Zarqa University attributed to the variable (academic level).

\section{Theoretical Framework and Literature Review}

\subsection{Theoretical Framework}

The first essential step in the strategic management process is to formulate a comprehensive vision for the organization. Each organization must have its own philosophy and thought that distinguishes it from other organizations, defines the purpose of its existence and sets the basic features of client satisfaction. This requires interaction of the university's leadership capabilities with the external and internal environment. The educational process in its core areas (student, teaching, curriculum, teaching methods, other facilities) became the focus of the external environment of the society due to the outputs of this university system, which serves all the service, industrial and other sectors. Increasingly these outputs, and must therefore face the future with appropriate strategies, which would maintain the survival and growth of the university, to be a decision maker with insight and vision in dealing with the future, (Masadeh, 2017)

Al-Khafaji (2010) defined the strategic vision as "the future direction and course of action of the organization that guides the organization to what it is trying to do in order to be in a privileged position in the future." (Rex \& Houze, 2002) See that "vision exists when individuals participate in a single organization in the values, beliefs, tasks and goals that must guide their behavior, an educational program shows the university trends on priority objectives and ways and means used and the climate university and thereby creating a collective mind determines certain standards of conduct for members of the university organization, a picture of what could be the future."

While the researchers see that the vision is: "an intellectual model for the optimal future and desirable for any organization, and the process of having a clear vision of the work and strategies to implement reality is an important feature of the University President and members who are characterized by modernity, without vision can not achieve success after the general direction to achieve University objectives ". Here management vision must be activated with the collective participation of members of the organization within the university organization.

The strategic vision is the foundation in building and achieving an effective strategy. The leader can not exercise his strategic decision-making in the absence of the concept of the future direction of the activity which includes many things including the quality of the client needs that must be met and the quality of the market position to be achieved In the face of competitors, (Idris, Mursi, 2015).

When the organization can establish a concrete perception of its market position and the quality of the tracks to follow, the strategic vision will be able to guide the decision-making process and define the organization's strategy, all of which contribute to real management value (Pairs, 2003).

It seems to define the vision by looking at the future status of the university which requires the development of specific strategies that correspond to reality, and enthusiasm among the staff of the university to participate actively in the implementation of the vision, and it is necessary to anticipate the expected achievements and determine the system of values and goals of university, focusing in a specific area which leads to a vision of implementation and its proximity to truth (Hussein, 2002).

The researchers point out that the vision goes beyond mere planning for the profits, activities, projects and programs of an organization. It is a future vision of the organization and a manifestation of its supreme policy. It is a partially challenging and worth working for, and be able to serve the internal customer.

\subsection{The Importance of Strategic Vision:}


The importance of the strategic vision is that it is the link between the university and the internal society and the environment. It defines the values and beliefs that will face the practical policy of the university in the future and is an important factor in the process of change. It is the application of modern teaching methods, or the presence of a team that leads an improvement and development campaign for one aspect of educational work (Al-Harthy, 2002).

Vision is an important role that goes beyond the start-up stage to all stages and the life cycle of the organization. It is a milestone that shows the way forward and the organization needs to be reoriented or transformed. This requires a new vision to ensure its continuity, (Al-Hosani, 2009).

\subsection{The Elements of Strategic Vision:}

1) A set of key elements of a strategic vision consists of the following:

2) Determining the future status that the university wishes to achieve, including the necessary change, clarity of the form, size and type of development that the vision wants to create, and the areas and activities it wishes to provide at the university in the future, (Al Owaisi, 2005).

3) Defining the goals that the vision seeks to achieve: by defining the main purpose of the university, and by anticipating the objectives that are expected to be achieved in order to achieve its vision of the future, and to determine what the university is different from and what is expected to achieve competition in the future. And the appropriate means and means to achieve them, Wheelen \& Hunger, 2004)

4) The culture of the university: The culture of the university is its personality and enviornment, which determines the appropriate behavior and linkages and motivates the workers. Hence, the concept of organizational culture is based on its foundations. The organizational culture of the university represents the beliefs, values, assumptions, rules, standards, During a given time, and thus determine the value system that helps to achieve the vision of the university and predict the impact of values and principles for the future of university work and the implementation of the vision of the university, (Masadeh, 2017)

5) Selection of the appropriate strategy: Strategic choice Decision within the decision-making process with attention to the relationship between the individual and the organization and the environment. This decision is influenced by the level of ambition of the decision maker and the objectives of the previous performance. The chosen alternative can achieve achievements at the level of the level of activity and the strategic level of the organization. The university leader should look for strategies that will support the realization of the vision and how it can be applied on the ground, Wilcoxson, Jesse, 2012).

\section{Client Relationship Management}

The client is the center of interest for companies at the moment being the main focus of marketing activities, which will not succeed and achieve their objectives unless they are designed and developed by the philosophy of understanding the behavior of the customer, by understanding the needs, desires and availability at the appropriate time and place and quality, taking into account the changing trends and tastes customers. Which requires them to establish a strong relationship with customers, and to retain the largest number of them, to establish an interactive dialogue with them, and to strengthen relations, whether using technology or ordinary (Khanfar and etal, 2015).

Client relationship management refers to: "a set of philosophical elements that place business customers at the product design point, by channeling their resources and efforts to gain more client loyalty, as well as providing the best services to these customers" (Janjicek, 2004).

Geenberg (2002) defines client relationship management as: "A strategy in business organizations that is fully seeking for the client itself. The client is the focus of his interest, to reach his satisfaction and to gain his trust. This strategy also seeks to maintain and acquire this customer, and provide a distinct service to him."

Bygstad (2000) defined it as "the philosophy that allows business organizations to understand how their customers think, analyze their needs and know what they are looking for, using the databases stored by the business, ultimately leading the organization to what they want In the future, predict their future behavior, and make timely marketing and marketing decisions in order to maintain the profitability of the company's business as well as its development."

Organizations are seeking to have a better relationship with their customers. The stronger the relationship with customers is, the greater the level of excellence in this organization or that of its competitors. Good relations with customers are the most important determinants of competitive advantage with similar organizations. The company should work to strengthen and develop these relations with customers, and maintain them at a clear level of strength, which will increase the amount of communication between the organization and its customers, especially if the 
organization can achieve this, which allows the organization the possibility of continuous communication with customers, Listen to their suggestions, and s Paul's ideas, these aspects have great value in the development of the organization's performance, and the preservation of capital, especially if that communication is directed to the permanent customers of that organization (Dulaimi and Najla, 2013).

Client relationship management is designed to retain selected customers in the long term. It is characterized by the collection and integration of data related to these customers, the use of automated information programs for data analysis, and the division of these customers according to their expected permanent value, And to consider the division of the market, even partially according to the wishes of customers, and to create value for customers through these operations, and provide service to these customers, and change in the organization to serve the interest of purchasing, based on the data and information for the entire organizational structure of that organization (Azzam, 2014).

Hence it is important that these organizations recognize their customers' wishes, needs and aspirations to gain more customers, retain former customers, and raise their loyalty to the business (Hanvanich, 2003).

This means that Client Relationship Management must have a sufficient set of personal data belonging to a group of profitable customers, and this personal data must be analyzed in order to obtain sufficient information about that customer, allowing the organization to retain that client, And raise the amount of confidence in this organization, which makes it achieve the greatest possible benefit from the profitability of this distinguished customer, (Shibail, 2012).

\section{Literature Review}

1. Al-Harthy, 2006, a study entitled: Indicators of strategic planning in the colleges of girls in Saudi universities from the point of view of faculty members.

The study aims at uncovering the availability of strategic planning indicators in the faculties of girls in Saudi universities and the relation with some variables. The sample of the study was from female college workers in Saudi universities for the academic year 2006 that fall within the job title as dean of college, head of department and faculty member. (215) questionnaires were distributed. The study included (36) items divided into four areas: the field of the message, the field of values, the field of strategic objectives, and the field of future vision of the annual university education. The results showed that the degree of availability of strategic planning indicators in the colleges of girls in Saudi universities from the point of view of the members of the faculty was in a medium degree, and there were significant differences at the level of significance $(0.05=\alpha)$ in the availability of strategic planning indicators in the colleges of girls in Saudi universities According to the variables of the study.

2. Alhusani, 2009, a study entitled: The degree of implementation of strategic planning stages in the Ministry of Education in the Sultanate of Oman.

The study aims at identifing the degree of implementation of the stages of the strategic planning process in the Ministry of Education in the Sultanate of Oman. The study community consists of all the administrative authorities of the Ministry of Education in the Sultanate of Oman (728). A random sample was chosen from 391 individuals, The study concluded that the degree of implementation of the stages of the strategic planning process by the administrative authorities in the Ministry of Education in the Sultanate of Oman was moderate at all stages of the strategic planning process. There were no statistically significant differences at the level of significance $(0.05=\alpha)$ to the extent of applying the stages of the strategic planning process by the administrative authorities in the Ministry of Education in Oman due to the variable job title.

3. Alhaiou, 2011, a study entitled: A Study on the Relationship between E-CRM Features and Loyalty: the Case in UK.

The study aims at studing the relationship between the characteristics of e-client relationship management at various stages of the transaction cycle (pre-purchase stage, purchasing stage or post-purchase), and its impact on client satisfaction, and in enhancing the loyalty of customers on the Internet at various stages of the purchasing cycle of mobile phone companies in the United Kingdom. A total of 380 questionnaires were distributed to students of Brunel University, west of London: the United Kingdom. The study found that using the characteristics of e-client relationship management in building relationships with customers has a significant impact on the loyalty and satisfaction of customers on the company's website, especially the ability to search the website for information, the existence of loyalty programs, and the feeling of client confidence when purchasing through the company's website, the existence of several payment 
methods that the client can choose from when making the purchase, and the provision of effective and responsive client services, which enhances the satisfaction and loyalty of customers and stay loyal to the site of the mobile phone company.

4. Abu Daqqa and Al-Dajni, 2011, a study entitled: Institutional self-evaluation and strategic planning and their role in quality assurance in Palestinian universities (Islamic University of Gaza as a case study).

The study aims at identifing the experience of self-evaluation in the Palestinian universities and its reflection on the strategic planning process. The study focused on the experience of the Islamic University in Gaza as a case study. The study tackled a research problem related to the processes of self-evaluation and strategic planning and their role in quality assurance in the university. The study followed the descriptive analytical method. The following outputs: Institutional self-evaluation criteria that have been developed and explained how they are used, the steps of the process of implementing the self-assessment and institutionalization and the models applied, and the experience of linking the results of the institutional evaluation process with the strategic planning of the university through an integrated model.

5. Kocoglu \& Kirmaci, 2012, a study entitled: Client Relationship Management and Loyalty: A Survey in the Sector of Banking.

The study aims at identifing the impact of client relations management in the Turkish banking sector. This study focused on the experience of Zirat Bank in achieving client loyalty in all branches of Dunsley. The questionnaire was used to achieve the objectives of the study. They work to meet customers' demands quickly, and the Bank has a strong ability to overcome critical issues and its customers are characterized by a high degree of loyalty.

6. Al-Sane', 2013, a study entitled: The degree of practicing the deans of the intermediate university faculties in the central governorates of strategic planning and its relation to the level of quality assurance from their point of view in the Hashemite Kingdom of Jordan.

The study aims at identifying the degree of accreditation of the deans and vice-presidents of the intermediate academic colleges for strategic planning and their relation to the level of quality assurance from their point of view. The study population of all the middle university colleges in the Hashemite Kingdom of Jordan of the University of Balqa Applied was administratively, financially, academically and technically. In order to achieve the objective of the study, three governorates were selected from the center by means of the sample of sample. The sample consisted of (47) deans and vice- deans. Where the researcher developed two questionnaires: the first on strategic planning and the second on quality assurance. The study found that the degree of practice of the deans of the intermediate university colleges in the central governorates of strategic planning from the point of view of the deans and their deputies was high. And that the level of quality assurance for the deans of middle university colleges in the central governorates from the point of view of the deans and their deputies was medium.

7. Sahoo \& Sahoo, 2013, a study entitled: Crm in Indian Banking Sector

The study aims at identifing the important factors that affect the process of selecting a client for a bank, namely: quality of service, effectiveness of marketing programs and good treatment with customers. In addition to knowing the role of bank employees in achieving client satisfaction, the study found that there was a divergence of client opinion about the impact of these dimensions on the customer's choice of a particular bank. The study indicated that a group of high-profile companies operating in India (ANDHARA, CITI, IDBI \& ICIC, HDFC) The client s selected differ in their views on these factors, The quality of service factor influenced their choice of dealing with ANDHARA \& CITI Bank, while another group of client s showed that the most important factor influencing them was the effectiveness of the marketing programs in selecting IBDI and HDFC Bank. The most important factor influencing their selection was ICICI.

8. Azzam, 2014, a study entitled: The impact of Client Relationship Management on Client Satisfaction in Banking Industry (a case of Jordan)

This study aims at identifing the impact of client relations management on client satisfaction in the Jordanian banking sector. The study population consisted of all commercial banks in Jordan. A random sample of 528 individuals was selected. A questionnaire was designed to achieve the objectives of the study. The study found that there is no statistically significant relationship between the elements of client relationship management and client satisfaction.

\section{Statistical Analysis and Hypothesis Testing}




\subsection{First: Characteristics of the Study Sample}

The total number of respondents was 115 faculty members and the following is an explanation of their characteristics

Table (1) shows the distribution of the study sample by demographic characteristics:

Table (1). Demographic Characteristics of the Study Sample

\begin{tabular}{|c|c|c|c|}
\hline Characteristics & Subcategories & Total & Percentage $\%$ \\
\hline \multirow{2}{*}{ Gender } & Femal & 27 & $23.5 \%$ \\
\hline & Male & 88 & $76.5 \%$ \\
\hline \multirow{4}{*}{ age categories } & Under 30 years & 15 & $13 \%$ \\
\hline & $30-40$ years & 24 & $21 \%$ \\
\hline & $40-40$ years & 60 & $52 \%$ \\
\hline & Over 50 years & 16 & $14 \%$ \\
\hline \multirow{5}{*}{ Job title } & University President & 0 & $0 \%$ \\
\hline & $\begin{array}{l}\text { Vice President of } \\
\text { University }\end{array}$ & 2 & $2 \%$ \\
\hline & Dean & 12 & $10 \%$ \\
\hline & Deputy Dean & 9 & $8 \%$ \\
\hline & Faculty member & 92 & $80 \%$ \\
\hline \multirow{4}{*}{ Years of Experience } & Under 5 & 21 & $15 \%$ \\
\hline & $5-10$ & 38 & $33 \%$ \\
\hline & $11-15$ & 40 & $38 \%$ \\
\hline & Over 15 & 16 & $14 \%$ \\
\hline \multirow[b]{2}{*}{ Qualification } & MA & 15 & $13 \%$ \\
\hline & PHd & 100 & $87 \%$ \\
\hline \multirow{4}{*}{ Academic level } & Professor & 14 & $12 \%$ \\
\hline & Associate & 32 & $28 \%$ \\
\hline & Assistant & 54 & $47 \%$ \\
\hline & Lecturer & 15 & $13 \%$ \\
\hline
\end{tabular}

The above table shows several results, the most prominent of which is that the majority of the respondents are faculty members $(80 \%)$. They are $\mathrm{PhD}$ holders and assistant professors, and the majority of the sample has reasonable teaching experience exceeding five years.

\subsection{Testing Hypotheses}

The first hypothesis:

There is no statistically significant effect at the level of significance $(\alpha \alpha \leq 0.05)$ for the strategic vision elements of (determining future status, goal setting, university culture, and choice of appropriate strategies) in internal client relations management at Zarqa University.

The following sub-assumptions emerge:

There is no statistically significant effect at the level of significance $(\alpha \leq 0.05)$ for the element of determining the future status in internal client relations management at Zarqa University.

Table (2) shows the variance analysis to measure the effect of the independent variable on the dependent variable: 
Table (2). Analysis of variance to measure the impact of future status determination on internal client relationship management:

\begin{tabular}{llcccccc}
\hline $\begin{array}{l}\text { The } \\
\text { dependent } \\
\text { variable }\end{array}$ & $\begin{array}{l}\text { Source of } \\
\text { Contrast }\end{array}$ & $\begin{array}{l}\text { Total } \\
\text { squares }\end{array}$ & $\begin{array}{l}\text { Degree } \\
\text { of } \\
\text { freedom }\end{array}$ & $\begin{array}{l}\text { Average } \\
\text { squares }\end{array}$ & $\begin{array}{l}\text { Calculated } \\
\text { F value }\end{array}$ & $\begin{array}{l}\text { Level of } \\
\text { significance }\end{array}$ & $\begin{array}{l}\text { The coefficient } \\
\text { of } \\
\text { determination } \\
\text { R2 }\end{array}$ \\
\hline $\begin{array}{l}\text { Internal } \\
\begin{array}{l}\text { Client } \\
\text { Relationship } \\
\text { Management }\end{array}\end{array}$ & $\begin{array}{l}\text { Regression } \\
\text { The error }\end{array}$ & 401.084 & 1 & 401.023 & & & \\
\hline
\end{tabular}

As shown in the above table, the coefficient for determining the relationship between the independent variable (determining the future situation) and the dependent variable (internal client relationship management) is significant (0.38) meaning that the percentage of change in internal client relations management at Zarqa University can be attributed to the effect (0.000). Based on the above, nullification and acceptance of the alternative hypothesis will be rejected in the sense that there is significant statistical significance at the level of significance $(\alpha \leq 0.05)$ for the effect of determining the future status of internal client relations management at the University Blue, and we also find that the model $r$ Or simple moral Adi regression equation. Table (3) below shows the simple regression analysis of the relationship between the two variables to determine the importance and effect of the independent variable and to contribute to the mathematical model that tests the effect of determining the future status of the university on the dependent variable.

Table (3). Results of simple regression analysis to measure the effect of future status determination at Zarqa University on the variable "internal client relationship management"

\begin{tabular}{|c|c|c|c|c|c|}
\hline $\begin{array}{l}\text { Independent } \\
\text { dimension }\end{array}$ & $\mathrm{B}$ & Standard error & Beta & $\begin{array}{ll}\text { Calculated } & T \\
\text { value } & \end{array}$ & $\begin{array}{l}\text { Level of } \\
\text { significance }\end{array}$ \\
\hline $\begin{array}{l}\text { Determine } \\
\text { future status }\end{array}$ & 0.895 & .001 & .81 & 14.803 & 0.000 \\
\hline
\end{tabular}

As shown in the table above, the independent variable has a significant effect by the statistical significance level $(\alpha \leq 0.001)$, which is the mathematical model variable or the simple regression equation estimated.

There is no statistically significant effect at the level of significance $(\alpha \leq 0.05)$ for the goal setting element in internal client relationship management, at Zarqa University.

Table (4) shows the variance analysis to measure the effect of the independent variable on the dependent variable

Table (4). Analysis of variance Measuring the effect of goal setting on internal client relationship management

\begin{tabular}{llllllll}
\hline $\begin{array}{l}\text { The } \\
\text { dependent } \\
\text { variable }\end{array}$ & $\begin{array}{l}\text { Source of } \\
\text { Contrast }\end{array}$ & $\begin{array}{l}\text { Total } \\
\text { squares }\end{array}$ & $\begin{array}{l}\text { Degree } \\
\text { of } \\
\text { freedom }\end{array}$ & $\begin{array}{l}\text { Average } \\
\text { squares }\end{array}$ & $\begin{array}{l}\text { Calculated } \\
\text { F value }\end{array}$ & $\begin{array}{l}\text { Level of } \\
\text { significance }\end{array}$ & $\begin{array}{l}\text { The coefficient } \\
\text { of } \\
\text { determination } \\
\text { R2 }\end{array}$ \\
\hline $\begin{array}{l}\text { Internal } \\
\begin{array}{l}\text { Client } \\
\text { Relationship } \\
\text { Management }\end{array}\end{array}$ & $\begin{array}{l}\text { Regression } \\
\text { The error }\end{array}$ & 502.011 & 1 & 488.014 & & & \\
\hline
\end{tabular}

As shown in the table above, the coefficient for determining the relationship between the independent variable (goal setting) and the dependent variable (internal client relationship management) is significantly large (0.41). In other words, the ratio of (41\%) in internal client relations management at Zarqa University can be attributed to the effect (0.000). Based on the above, nullification and acceptance of the alternative hypothesis will be rejected in the sense that there is significant statistical significance at the level of significance $(\alpha \leq 0.05)$ for the effect of 
targeting on the internal client relations department at Zarqa University, We also find that the mathematical model or together The regression of the simple regression is significant. Table (5) below shows the simple regression analysis of the relationship between the two variables to determine the importance and effect of the independent variable and to contribute to the mathematical model that tests the effect of university goal setting on the internal client relationship management variable.

Table (5). Results of the simple regression analysis to measure the effect of setting goals in Zarqa University on the variable "internal client relationship management"

\begin{tabular}{cccccc}
\hline $\begin{array}{c}\text { Independent } \\
\text { dimension }\end{array}$ & B & Standard error & Beta & $\begin{array}{c}\text { Calculated T } \\
\text { value }\end{array}$ & $\begin{array}{c}\text { Level of } \\
\text { significance }\end{array}$ \\
\hline Setting goals & 0.991 & .004 & .91 & 15.00 & 0.000 \\
\hline
\end{tabular}

As shown in the table above, the independent variable has a significant effect by the statistical significance level $(\alpha \leq 0.001)$, which is the mathematical model variable or the simple regression equation estimated.

There was no statistically significant effect at the level of $(\alpha \leq 0.05)$ of the university culture component in internal client relations management at Zarqa University.

Table (6) shows the variance analysis to measure the effect of the independent variable on the dependent variable:

Table (6). Analysis of variance to measure the effect of culture at the university on the management of internal client relations

\begin{tabular}{cccccccc}
\hline $\begin{array}{c}\text { The dependent } \\
\text { variable }\end{array}$ & $\begin{array}{c}\text { Source of } \\
\text { Contrast }\end{array}$ & $\begin{array}{c}\text { Total } \\
\text { squares }\end{array}$ & $\begin{array}{c}\text { Degree } \\
\text { of } \\
\text { freedom }\end{array}$ & $\begin{array}{c}\text { Average } \\
\text { squares }\end{array}$ & $\begin{array}{c}\text { Calculated } \\
\text { F value }\end{array}$ & $\begin{array}{c}\text { Level of } \\
\text { significance }\end{array}$ & $\begin{array}{c}\text { The coefficient } \\
\text { of } \\
\text { determination } \\
\text { R2 }\end{array}$ \\
\hline $\begin{array}{c}\text { Internal Client } \\
\text { Relationship } \\
\text { Management }\end{array}$ & $\begin{array}{c}\text { Regression } \\
\text { The error }\end{array}$ & 502.011 & 1 & 498.11 & 21.90 & .000 & 0.44 \\
\hline
\end{tabular}

As shown in the table above, the coefficient of determination of the relationship between the independent variable (goal setting) and the dependent variable (internal client relationship management) is significantly large (0.44) meaning that the ratio of $(44 \%)$ change in internal client relations management at Zarqa University can be attributed to the effect (0.000). Based on the above, nullification and acceptance of the alternative hypothesis will be rejected in the sense that there is significant statistical significance at the level of significance $(\alpha \leq 0.05)$ for the influence of the prevailing culture in the university on the management of internal client relations University of Zarqa, and we also find that The mathematical model or the simple regression equation is significant. Table (7) below shows the simple regression analysis of the relationship between the two variables to determine the importance and effect of the independent variable and to contribute to the mathematical model that tests the influence of the university culture on the dependent variable.

Table (7). Results of the simple regression analysis for measuring the effect of the university culture at Zarqa University on the variable "internal client relations management"

\begin{tabular}{cccccc}
\hline $\begin{array}{c}\text { Independent } \\
\text { dimension }\end{array}$ & $\mathrm{B}$ & Standard error & Beta & $\begin{array}{c}\text { Calculated T } \\
\text { value }\end{array}$ & $\begin{array}{c}\text { Level of } \\
\text { significance }\end{array}$ \\
\hline $\begin{array}{c}\text { University } \\
\text { culture }\end{array}$ & 0.890 & .002 & .002 & .85 & 0.000 \\
\hline
\end{tabular}

1. There was no statistically significant effect at the level of significance $(\alpha \leq 0.05)$ for the selection of the appropriate strategy in internal client relations management at Zarqa University.

Table (8) shows the variance analysis to measure the effect of the independent variable on the dependent variable 
Table (8). Analysis of variance to measure the impact of selecting the appropriate strategy on managing internal client relationships

\begin{tabular}{cccccccc}
\hline $\begin{array}{c}\text { The } \\
\text { dependent } \\
\text { variable }\end{array}$ & $\begin{array}{c}\text { Source of } \\
\text { Contrast }\end{array}$ & $\begin{array}{c}\text { Total } \\
\text { squares }\end{array}$ & $\begin{array}{c}\text { Degree } \\
\text { of } \\
\text { freedom }\end{array}$ & $\begin{array}{c}\text { Average } \\
\text { squares }\end{array}$ & $\begin{array}{c}\text { Calculated } \\
\text { F value }\end{array}$ & $\begin{array}{c}\text { Level of } \\
\text { significance }\end{array}$ & $\begin{array}{c}\text { The } \\
\text { coefficient of } \\
\text { determination } \\
\text { R2 }\end{array}$ \\
\hline $\begin{array}{c}\text { Internal } \\
\begin{array}{c}\text { Client } \\
\text { Relationship } \\
\text { Management }\end{array}\end{array}$ & $\begin{array}{c}\text { Regression } \\
\text { The error }\end{array}$ & 487.080 & 1 & 455.081 & & & \\
\hline
\end{tabular}

As shown in the above table, the coefficient of determining the relationship between the independent variable (the choice of the appropriate strategy) and the dependent variable (internal client relationship management) is large (0.31). In other words, the ratio of (31\%) in internal client relations management at Zarqa University can be attributed to the effect $(0,000)$. Based on the above, nullity and acceptance of the alternative hypothesis will be rejected in the sense that there is significant statistical significance at the level of significance $(\alpha \leq 0.05)$ for the effect of choosing the appropriate strategy for managing internal client relations at Zarqa University, And we find The mathematical model or simple regression equation is significant. Table (9) below shows the simple regression analysis of the relationship between the variables to determine the importance and effect of the independent variable and the contribution to the mathematical model that tests the effect of selecting the appropriate strategy in the university on the dependent variable.

Table (9). Results of simple regression analysis to measure the effect of selecting the appropriate strategy at Zarqa University on the variable "internal client relations management"

\begin{tabular}{cccccc}
\hline $\begin{array}{c}\text { Independent } \\
\text { dimension }\end{array}$ & $\mathrm{B}$ & Standard error & Beta & $\begin{array}{c}\text { Calculated T } \\
\text { value }\end{array}$ & $\begin{array}{c}\text { Level of } \\
\text { significance }\end{array}$ \\
\hline $\begin{array}{c}\text { Choose the } \\
\text { appropriate } \\
\text { strategy }\end{array}$ & 0.760 & .003 & .801 & 15.304 & 0.000 \\
\hline
\end{tabular}

The first hypothesis:

There were no statistically significant differences $(\alpha \leq 0.05)$ between the responses of the study sample members on the adoption of strategic vision elements in the management of internal client relations, due to the personal and functional characteristics of (gender, age groups, job title, years of experience , Academic qualification, and academic rank) and the following sub-assumptions:

In order to test this hypothesis and its sub-hypotheses related to the existence of statistically significant differences in the availability of the dimensions of the empowerment of the work teams according to the demographic characteristics of the sample of the study, the test of the unidirectional variance analysis was used to show the differences in the response averages for the subcategories of each demographic. Table (10): The product of the analysis of the variance of the differences:

Table (10). Analysis of the variance of the variance of the mean variance in the sub-categories of each demographic

\begin{tabular}{ccccccc}
\hline $\begin{array}{c}\text { Independent } \\
\text { variable }\end{array}$ & $\begin{array}{c}\text { Source of } \\
\text { Contrast }\end{array}$ & Total squares & $\begin{array}{c}\text { Degree of } \\
\text { freedom }\end{array}$ & $\begin{array}{c}\text { Average } \\
\text { squares }\end{array}$ & $\begin{array}{c}\text { Calculated F } \\
\text { value }\end{array}$ & $\begin{array}{c}\text { Level of } \\
\text { significance }\end{array}$ \\
\hline Gender & $\begin{array}{c}\text { Between } \\
\text { groups }\end{array}$ & 77.0 & 3 & 69.4 & & \\
& $\begin{array}{c}\text { Within } \\
\text { groups }\end{array}$ & 34.0 & 99 & 28.2 & 18.889 & 0,000 \\
$\begin{array}{c}\text { Between } \\
\text { age }\end{array}$ & 89.0 & 3 & 86.6 & 19.55 & 0,000 \\
categories & Within & 39.0 & 99 & 30.0 & &
\end{tabular}




\begin{tabular}{|c|c|c|c|c|c|c|}
\hline \multirow{4}{*}{ Job title } & & & & & \multirow{4}{*}{22.25} & \multirow{4}{*}{0,000} \\
\hline & Between & 182 & 2 & 294 & & \\
\hline & groups & 40.3 & 5 & 29.4 & & \\
\hline & $\begin{array}{l}\text { Within } \\
\text { groups }\end{array}$ & 1708.590 & 99 & 12.40 & & \\
\hline \multirow[t]{2}{*}{$\begin{array}{l}\text { Years of } \\
\text { Experience }\end{array}$} & $\begin{array}{c}\text { Between } \\
\text { groups }\end{array}$ & 38.224 & 3 & 13.224 & \multirow{2}{*}{24.14} & \multirow{2}{*}{0,000} \\
\hline & $\begin{array}{l}\text { Within } \\
\text { groups }\end{array}$ & 4159.289 & 99 & 31.88 & & \\
\hline \multirow[t]{2}{*}{ Qualification } & $\begin{array}{c}\text { Between } \\
\text { groups }\end{array}$ & 38.22 & 3 & 8.224 & \multirow{2}{*}{4.14} & \multirow{2}{*}{0,09} \\
\hline & $\begin{array}{l}\text { Within } \\
\text { groups }\end{array}$ & 26.05 & 99 & 14.40 & & \\
\hline \multirow[t]{2}{*}{$\begin{array}{l}\text { Academic } \\
\text { level }\end{array}$} & $\begin{array}{c}\text { Between } \\
\text { groups }\end{array}$ & 38.224 & 3 & 18.224 & \multirow{2}{*}{6.10} & \multirow{2}{*}{0,007} \\
\hline & $\begin{array}{l}\text { Within } \\
\text { groups }\end{array}$ & 32.0 & 99 & 11.421 & & \\
\hline
\end{tabular}

The first sub-hypothesis: There are no statistically significant differences at the level of significance $(\alpha \leq 0.05)$ between the responses of the sample members on the adoption of elements of strategic vision in the management of internal client relations at Zarqa University attributed to the variable (gender).

Table (10) shows significant statistical differences between the responses of the study sample members on the adoption of the strategic vision elements in the internal client relationship management at Zarqa University due to the variable (gender) and its significance $(0.000)$. Based on the results, $(\alpha \leq 0.05)$ in the responses of the study sample members on the adoption of the elements of strategic vision in the management of internal client relations at Zarqa University attributed to the gender variable.

The second sub-hypothesis: There are no statistically significant differences at the level of significance $(\alpha \leq 0.05)$ between the responses of the sample members on the adoption of elements of strategic vision in the management of internal client relations at Zarqa University attributed to the variable (age categories).

Table (10) shows significant statistical differences between the responses of the study sample members on the adoption of the strategic vision elements in the internal client relationship management at Zarqa University due to the variable (age categories) and its significance (0.000). Based on the results, $(\alpha \leq 0.05)$ in the responses of the study sample members on the adoption of the elements of strategic vision in the management of internal client relations at Zarqa University attributed to the age categories variable.

The third sub-hypothesis: There are no statistically significant differences at the level of significance $(\alpha \leq 0.05)$ between the responses of the sample members on the adoption of elements of strategic vision in the management of internal client relations at Zarqa University attributed to the variable (Job title).

Table (10) shows significant statistical differences between the responses of the study sample members on the adoption of the strategic vision elements in the internal client relationship management at Zarqa University due to the variable (Job title) and its significance $(0.000)$. Based on the results, $(\alpha \leq 0.05)$ in the responses of the study sample members on the adoption of the elements of strategic vision in the management of internal client relations at Zarqa University attributed to the Job title variable.

The forth sub-hypothesis: There are no statistically significant differences at the level of significance $(\alpha \leq 0.05)$ between the responses of the sample members on the adoption of elements of strategic vision in the management of internal client relations at Zarqa University attributed to the variable (Years of Experience).

Table (10) shows significant statistical differences between the responses of the study sample members on the adoption of the strategic vision elements in the internal client relationship management at Zarqa University due to the variable (Years of Experience) and its significance (0.000). Based on the results, $(\alpha \leq 0.05)$ in the responses of the study sample members on the adoption of the elements of strategic vision in the management of internal client relations at Zarqa University attributed to the Years of Experience variable.

The fifth sub-hypothesis: There are no statistically significant differences at the level of significance $(\alpha \leq 0.05)$ between the responses of the sample members on the adoption of elements of strategic vision in the management of internal client relations at Zarqa University attributed to the variable (Qualification). 
Table (10) shows significant statistical differences between the responses of the study sample members on the adoption of the strategic vision elements in the internal client relationship management at Zarqa University due to the variable (Qualification) and its significance (0.000). Based on the results, $(\alpha \leq 0.05)$ in the responses of the study sample members on the adoption of the elements of strategic vision in the management of internal client relations at Zarqa University attributed to the Qualification variable.

The sixth sub-hypothesis: There are no statistically significant differences at the level of significance $(\alpha \leq 0.05)$ between the responses of the sample members on the adoption of elements of strategic vision in the management of internal client relations at Zarqa University attributed to the variable (Academic level).

Table (10) shows significant statistical differences between the responses of the study sample members on the adoption of the strategic vision elements in the internal client relationship management at Zarqa University due to the variable (Academic level) and its significance (0.000). Based on the results, $(\alpha \leq 0.05)$ in the responses of the study sample members on the adoption of the elements of strategic vision in the management of internal client relations at Zarqa University attributed to the Academic level variable.

\section{Conclusions and Recommendations}

First: Conclusions: Based on the findings of the study through statistical analysis and hypothesis testing, a number of important aspects and conclusions can be deduced from this study, as follows:

In the demographic characteristics of the study sample, the study concluded that:

a. The percentage of male faculty members in the University of Zarqa increases significantly. The explanation of the result may be due to the lack of opportunity for females to complete their higher studies and to obtain master's and doctorate degrees.

b. The large percentage of faculty members is young age groups that are less than fifty years old. This is a good indicator of the serious attitudes of many citizens to complete their higher education at the very earliest ages.

c. There are a good proportion of university faculty members who have high academic grades as associate professor and professor. This indicates that there is support and encouragement for the promotion movement at the university by encouraging faculty members to conduct and publish scientific research.

d. On the other hand, there is a small percentage of faculty members at the university who have a master's degree and must provide them with the opportunity to complete their studies and obtain a doctorate degree.

e. The results of the statistical analysis showed a clear effect of the strategic vision elements of: determining future status, goal setting, university culture, selecting the appropriate strategies for internal client relations management at Zarqa University. (0.44), followed by the strength of the effect on the internal client relationship management as a factor (goal setting) and the R2 identification coefficient of the relationship $(0.41)$.

f. The results of the statistical analysis showed that there were significant differences at the level of significance $(0.05>\alpha)$ between the responses of the study sample members on the adoption of strategic vision elements in the management of internal client relations attributed to each variable (gender, age group, job title Years of experience).

g. It was found that there were no significant differences at the level of significance $(0.05>\alpha)$ between the responses of the sample of the study on the adoption of elements of strategic vision in the management of internal client relations attributed to each of the variables of academic qualification and academic level.

\section{Recommendations}

To improve the university's ability to manage internal client relations by focusing on strategic vision elements, the researchers provide the following recommendations:

1. The interest of the university administration in spreading the positive culture and strengthening it among the faculty members.

2. The administration of the university shall set specific goals for the next stage so as to be clear to all employees of the university.

3. The administration of the university to build clear future strategic directions, and update the vision and mission of the university.

4. The researchers recommend to expand the study of the impact of strategic factors and other organizational factors and programs and plans of administrative development to improve the management of relations with 
the internal client of the University.

\section{Research References}

Adris, T. A., \& Morsi, M. J. (2015). Strategic Management: Applied Concepts and Models, University House, University for Printing, Publishing and Distribution.

Al, O., \& Rajab, B. A. (2005). Strategic Vision of the Modern School Principal. paper presented to the Fifth Conference in Saudi Arabia.

Alhaiou, T. (2011). A Study on the Relationship between E-CRM Features and ELoyalty the case in UK. phd, Brunel University west London, Brunel Business school.

Al-Hosani, M. (2009). The Degree of Implementation of the Stages of the Strategic Planning Process in the Ministry of Education in the Sultanate of Oman. Journal of Studies, Educational Sciences, 36.

Al-Khafaji, \& Nima, A. (2010). (Strategic Management Approaches, Concepts and Processes). Dar Al-Thaqafa for Publishing and Distribution, Amman-Jordan.

Azzam, Z. (2014). The Impact of Client Relationship Management on Client Satisfaction in the Banking Industry - A Case of Jordan, European Journal of Business and Management, ISSN 2222-1905 (Paper) ISSN 22222839 (Online), 6.

Bygstad, B. (2003). The implementation Puzzle of CRM systems in Knowledge- based organization. Information Resources Management Joumal, 16.

Dahawi, B., \& Al-Malihi, R. (2011). Strategic Planning in Education, Cairo, Arab Thought House.

Dulaimi, O. N. (2013). Role of Client Relationship Management in Achieving Loyalty, A Survey of a Sample of Employees in a Aumber of Private Banks, in the City of Mosul. Iraqi Academic Scientific Journals, 35(114).

Greenberg, P. (2002). CRM at the Speed of Light, McGraw-Hill/Osborne, Emeryville, CA.

Hanvanich, S., Droge, C., \& Calantone, R. (2003). Reconceptualizing the meaningand domain of marketing knowledge. Journal of Knowledge Management, 7.

Hussein, H. (2002). A Proposal for the Implementation of Strategic Planning in the Egyptian University Education. Journal of Education, Egyptian Association for Comparative Education and Educational Management, Egypt.

Janjicek, R. (2004). CRM architecture for enterprise relationship management in the millennium. a technical white paper by CHP, www. Looksmark.com.

Kocoglu \& Kirmaci (2012). Client Relationship Managmenet and Loyalty: A Survey in the Seector of Banking. International Journal of Business and Social Science, 3(3).

Kotler, P., \& Armstrong, G. (2014). Principles of marketing (14th ed). new jersey: Prentice hall.

Masadeh, M. (2017). Strategic Management: Operations Concepts, Applied Cases, Amman, Dar Al Masirah for Publishing, Distribution and Printing.

Paris, K. A. (2003). Strategic Planning In the university, (Ph.D.), Quality university of Wisconsin system board of regents.

Rex, Houze (what makes leader different) 2002. WWW. Career know how. Com/ Ldr-sdifferent.htm.

Sahoo \& Sahoo (2013). Crm in IndianBanking Setcor. VSRD International Journal of Business and Management Research, 3(4).

Sakran, M. (2003). Towards a Contemporary Vision of University Jobs: In Light of the Challenges of the Future, Cairo, Dar Al-Huda Printing.

Wheelen, T. H., \& Hunger, J. D. (2004). Strategic Management and Business Policy, New York: Addison - Wesley Publishing Co.

Wilcoxson, J. (2012). Strategic planning implementation: A case study of California community college (Ph.D.), California state University, san Francisco.

\section{Copyrights}

Copyright for this article is retained by the author(s), with first publication rights granted to the journal.

This is an open-access article distributed under the terms and conditions of the Creative Commons Attribution 
license (http://creativecommons.org/licenses/by/4.0/). 